\title{
Thickness of Moist Sludge Piling from Community Wastewater Treatment through the Royal LERD Technology for Growing Rice
}

\author{
Nuta Supakata (Corresponding author) \\ College of Environment, Kasetsart University \\ 50 Phahon Yothin Rd, Chatuchak Bangkok 10900, Thailand \\ Tel: 669-135-5139 E-mail: nuta.s@chula.ac.th \\ Prof. Kasem Chunkao \\ College of Environment, Kasetsart University \\ 50 Phahon Yothin Rd, Chatuchak Bangkok 10900, Thailand \\ Tel: 662-579-2116 E-mail: ecksc@ku.ac.th
}

Received: November 16, 2010 Accepted: November 30, 2010 doi:10.5539/jas.v3n3p93

The research is financed by the King's Royally Initiated Leam Phak Bia Environmental Research and Developmental Project

\begin{abstract}
Using moist sewage sludge as a new source for growing rice is an alternative community wastewater treatment with agricultural benefit and ease management (saves time and space). The experimental study was conducted to investigate the potential of using the moist sludge from community wastewater treatment in growing rice (Oryza sativa L.:Chinat1 rice cultivar). In this experiment, the sludge was divided into 21 treatments, which could be categorized by the level of piling depth and the sun drying time. The sludge was piled at the depth of $10 \mathrm{~cm}$ (H10), $20 \mathrm{~cm}(\mathrm{H} 20)$ and $30 \mathrm{~cm}$ (H30). For sun drying of moist sludge, the sun exposure time was varied from 0-18 days, 0 day (D0), 3 days (D3), 6 days (D6), 9 days (D9), 12 days (D12), 15 days (D15) and 18 days (D18). The results showed that moist sewage sludge piled at the depth of $30 \mathrm{~cm}$ can be used to grow rice (Oryaza sativa L) under the present set of experimental conditions with sufficient nitrogen.
\end{abstract}

Keywords: Moist sewage sludge, Rice (Oryza sativa L.)

\section{Introduction}

Sewage sludge is residue generated from the wastewater treatment process as a result of the treatment of wastewater released from a variety of sources including homes, industries, medical facilities, street runoff and businesses. Each year Thailand generates approximately 63,000 tons of dry solid sewage sludge (Stoll, 1995) and this trend will increase many fold in the years to come. The continual increase of sewage sludge has caused negative economic and health effects. Many methods of sewage sludge disposal have been proposed including landfill, incineration, ocean dumping and use as fertilizer. Ocean dumping of sludge has been forbidden in the U.S. since 1991 (U.S. Environmental Protection Agency, 1999). Landfilling of sludge has been an inexpensive method of disposal but requires more land to fill. Incineration reduces the sludge to ash, which can then be used for landfill, but in most cases, more fuel is needed to burn the sludge into ash, which makes this method less economical (Dolgen et al., 2007 and Li et al., 2009). Sewage sludge has become a major problem in many cities in the world due to rapid population growth and urbanization. Bangkok Metropolitan Administration (BMA) is faced with the same problem. The population of Bangkok increased from 5.6 million in 2000 to 5.7 million in 2008 (BMA, 2008). This lead to an increase of sewage sludge accumulation, which has been produced at approximately 600 tons per day dry solid concentration.

From chemical analysis of digested sludge, the BMA has shown that this sludge contains numerous constituents which has a high amount of organic matter (19.89\%), total nitrogen (3.34\%), total phosphorus $(1151 \mathrm{mg} / \mathrm{kg}) \mathrm{and}$ other micro-nutrients (Wattanaporn, 2001). Sewage sludge is rich in nutrients and organic matter which makes it beneficial for agricultural activities (Martinez et al., 2003). The enhanced biomass yield and an increase in organic matter content $(2.38 \%)$, nitrogen content $(0.20 \%)$, moisture content $(5 \%)$, porosity $(11 \%)$, water retention capacity, the increased microbial activity, respiration and enzymatic activities were reported in the soils amended with sludge (Epstein, 1975; Banerjee et al., 1997). As Bertoncini et al. (2008) reported that an addition 
of sludge to sandy soil results in an increase in C, N, P and Ca content and cation exchange capacity of the soil. Singh and Agrawal (2010) showed that sewage sludge amendment rates above $4.5 \mathrm{~kg} \mathrm{~m}^{-2}$ increased the yield of rice. Even in Thailand, there is much research involved in applying sewage sludge as organic fertilizer for agricultural works: Wattanaporn (2001) reported that the use of sewage sludge alone or in combination with urea to be equal to commercial forms of urea as another source for rice; Siriratpiriya et al. (2009) showed that chemical fertilizer and organic fertilizer could be replaced by sludge and rubber latex lutoid for nursering poly-bag rubber because of the high major elements $(\mathrm{N}, \mathrm{P}, \mathrm{K})$ and $\mathrm{Mg}$ in sludge.

In most cases, sludge must be dried and ground before utilizing in agricultural works which requires space for air drying and time for grinding the sludge. No such research has been reported on response of plants grown in moist sludge from a community wastewater treatment system. In order to use this waste for agricultural benefit with ease management (saving time and space), using moist sludge for planting rice has been conducted. The objective of this research is to investigate the potential of using the moist sludge from community wastewater treatment in growing rice (Oryza sativa L.: Chinat1 rice cultivar) at the King's Royally Initiated Leam Phak Bia Environmental Research and Developmental Project, Phetchaburi Province.

\section{Materials and methods}

\subsection{Study area}

The experiment was conducted at the experimental site of The King's Royally Initiated Leam Phak Bia Environmental Research and Developmental Project (the Royal LERD-project) at Phetchaburi Province, Thailand, a wastewater treatment site since 1991. The location of the LERD Project is settled in a sub-district of Laem Phak Bia, Ban Laem District, Petchaburi Province, in the south of the central part of Thailand. The size of the experimental area is approximately 480 acres plus of natural mangrove forest along a 300 meter-width mud beach of the Petchaburi river mouth. It was learnt that the experimental site used to be covered with sea water, and gradually mud settling with the consequences of mangrove tree succession. The barren shrimp farmland was left almost ten years before the Royal LERD Project took over the land for environmental research on community wastewater treatment.

The Royal LERD Project site at Laem Phak Bia sub-district has been divided into 4 parts; there are 5 oxidation ponds (37.84 acres), aquatic and grass filtration plots (1.08 acres), mangrove reforestation (14.83 acres), and an operation center (1.56 acres). Wastewater from the Petchaburi Municipality, which is comprised of 40,000 people at about $3,600 \mathrm{~m}^{3} /$ day has been pumped from the city wastewater collection pond to the Royal LERD Project site coming along the irrigation canals by the HDPE pipe. Actually, the Petchaburi Municipality produces approximately $5,000 \mathrm{~m}^{3}$ of wastewater per day but the pumping capacity is only about $3,600 \mathrm{~m}^{3} /$ day, some parts are flowing directly to Petchaburi River and the others are being trapped in pipes and swamps in the city itself. All wastewater streams from the municipal area of the Phetchaburi province flow and merge at the Yang Canal (Ta-Yang) pumping station, where large solids are removed. Then the wastewater treatment process starts pumping into an 18.5-kilometre pipeline to Laem Phak Bia to undergo a two-step treatment; the lagoon treatment system and the mangrove forest. The lagoon treatment system consists of five different ponds: one sedimentation pond, three oxidation ponds, and one polishing pond. The wastewater is treated gradually as the water flows from pond to pond before being drained into the mangrove forest. After the treatment, the water quality has met the acceptable standards. The sludge from wastewater treatment contains the dead microorganism and other organic matter. The accumulation of the sludge will cause the wastewater treatment processes to be ineffective. As in the Royal LERD Project site, annual mean of sediment load that accumulated in the oxidation ponds was approximately $3.23 \mathrm{ml} / 1$ with the average height of $11.83 \mathrm{~cm}$ which made the Royal LERD Project wastewater treatment system lose its capacity, up to 8 percent (Thepphituk, 2000). Therefore, to manage this waste, the sludge can be utilized as a nutrient resource for planting.

\subsection{Experimental design and sludge preparation}

The sludge was contained in acrylic pots having a diameter of $20 \mathrm{~cm}$ and a height of $20 \mathrm{~cm}, 30 \mathrm{~cm}$, and $40 \mathrm{~cm}$. In this experiment, the sludge was divided into 21 treatments, which could be categorized by the level of piling depth and the sun drying time. The sludge was piled at the depth of $10 \mathrm{~cm}(\mathrm{H} 10), 20 \mathrm{~cm}(\mathrm{H} 20)$ and $30 \mathrm{~cm}(\mathrm{H} 30)$. For sun drying of moist sludge, the sun exposure time was varied from 0-18 days, 0 day (D0), 3 days (D3), 6 days (D6), 9 days (D9), 12 days (D12), 15 days (D15) and 18 days (D18). There were three replications for each treatment, for a total of 63 pots ( $3 \times 7 \times 3$ Factorial in CRD). All 63 pots were located in a saran greenhouse having a light-intensity of 30,000 lux and the exposure time of 12-13.5 h per day.

For the sludge collection, an aluminum bucket connected to a bamboo trunk was used to obtain the sludge at the bottom of the sedimentation pond. The square sedimentation pond had one entrance and one exit on the opposite side. The sludge was collected from 5 locations, two at the corners of the entrance side, two at the corners of the 
exit side, and one at the center of the sedimentation pond by using a rowboat. The collected sludge was dewatered in a sack. All sludge from the 5 locations was mixed and put into 63 pots as mentioned earlier.

The sludge piling depth and sun drying time before planting used in the experiments are given in Table1. The difference in the piling depths caused the different weight of sludge which can be converted to the unit of ton/hectare. (Table1)

\subsection{Plant growth experiments}

The Chainat 1 (Oryza sativa L. cv. Chainat 1) was selected as a test plant. Chai Nat 1 (CNTBR82075-43-2-1), a non-glutinous rice, was derived from the cross IR13146-158-1/IR15314-43-2-3-3//BKN6995-16-1-1-2. It has a high yield, is photoperiod insensitive, takes 119-130 days to mature and grows to a height of $113 \mathrm{~cm}$. Its grain quality is straw hull color, long slender grain with slight chalkiness, good milling quality, and has high amylose content. It is resistant to major insect pests and diseases in the central region of Thailand such as the brown plant hopper, white backed plant hopper, ragged stunt virus disease and blast. The yield of this cultivar ranges between $0.45 \mathrm{~kg} \mathrm{~m}^{-2}$ in rainy season to $0.47 \mathrm{~kg} \mathrm{~m}^{-2}$ in dry season (Rice Research Institute, 2005).

Rice sprouts at the age of 30 days were grown in pots located in a saran greenhouse with sufficient sunlight. Watering was performed daily to have the water level of $5 \mathrm{~cm}$ above the sludge in order to maintain a water logged condition in each pot. The plants were grown for 120 days, approximately 4 months (from August to November 2009) and under normal temperature (mean temperature of $30^{\circ} \mathrm{C}$ ). During this period, neither additional sludge, nor any pesticides were applied.

\subsection{Sewage sludge analysis}

Sewage sludge samples were air dried, crushed and passed through a sieve of $2 \mathrm{~mm}$ mesh size. The $\mathrm{pH}$ of the sewage sludge was measured in a suspension of 1:5 (w/v). Total nitrogen content in the sewage sludge samples were determined by Kjeldahl method (Bremner, 1960). Organic matter was analyzed by the Walkey-Black method (Walkley and Black, 1934 and Schnitzer, 1982). Available phosphorus and total phosphorus in the samples were quantified by the Bray II method (Bray and Kurtz, 1945) and Vanadomolybdate (Olsen and Sommers, 1982) respectively. Exchangeable potassium, calcium and magnesium in sludge were extracted by neutral ammonium acetate extraction and analyzed by Atomic Absorption Spectrometer (Model GBC 908 AA) (McLean and Watson, 1982). To determine moisture of sludge, the samples were dried at $104^{\circ} \mathrm{C}$ for $24 \mathrm{~h}$, and moisture was determined as a percentage of dry weight.

For analysis of heavy metals in sewage sludge samples, a $1 \mathrm{~g}$ air-dried sample was digested in $20 \mathrm{ml}$ of tri acid mixture $\left(\mathrm{HNO}_{3}: \mathrm{H}_{2} \mathrm{SO}_{4}: \mathrm{HClO}_{4}: 5: 1: 1\right)$ for $8 \mathrm{~h}$ at $80^{\circ} \mathrm{C}$ following the method described by Allen et al. (1986). After complete digestion, the solution was filtered and the filtrate was analyzed for heavy metals. Heavy metal concentrations in sewage sludge were quantified using a $0.05 \mathrm{M}$ EDTA solution according to the method given by Quevauviller et al. (1997). A $10 \mathrm{~g}$ air-dried sample was shaken after mixing $20 \mathrm{ml}$ of $0.05 \mathrm{M}$ EDTA (pH 7) on a shaker for about $1 \mathrm{~h}$ and then allowed to stand overnight. The solution was filtered using Whatman No.42 filter paper and the filtrate was used for analysis. Heavy metal concentrations in the filterate were determined by using a flame Atomic Absorption Spectrometer (Model GBC 908 AA) on a dry weight basis.

\subsection{Analyses of growth parameters, biomass and yields}

Rice plants were finally harvested at 120 DAS (day after sowing) with no damage to roots. The number of ears was counted, and the stem length (from the sludge level to the end of the plant) was also measured. The stems and roots were washed with de-ionized water to remove any attached particles, and then they were dried at $80^{\circ} \mathrm{C}$ until constant weight was achieved. The dry weights of the stems and roots were then measured to determine the effect of various sludge piling depths and time for sun drying of moist sludge on the growth and yield of the Chinat 1 rice cultivar plants. Weight of specific number or volume of seed is known as the test weight. In this study, thousand seed weight was taken as the test weight. The harvest index (HI) was calculated as a ratio of weight of grains plant ${ }^{-1}$ to the aboveground biomass.

\subsection{Statistical analysis}

The data was subjected to one-way analysis of variance (ANOVA) using SAS version 9.1 for Windows. Duncan's multiple range test was used to assess the significance of the effects of these sludge loadings on plant growth and heavy metal amount accumulated in the plants

\section{Results and discussion}

\subsection{Characteristics of the sludge}

The sludge used for this experiment was neutral in $\mathrm{pH}(6.8)$ and had a high level of EC (12.51 ds $\left.\mathrm{m}^{-1}\right)$, CEC (34 $\left.\mathrm{cmol}\left(\mathrm{p}^{+}\right) \mathrm{kg}^{-1}\right)$ and $\mathrm{OM}(15.9 \%)$. Total nitrogen (1.05\%) was also high. The total of heavy metal concentrations 
showed the trend as follows, $\mathrm{Pb}>\mathrm{Cr}>\mathrm{Ni}>\mathrm{Hg}>\mathrm{Cd}>$ As. The physical and chemical properties of the sludge are presented in Table 2. (Table2)

According to the Thailand soil criteria for agricultural use, the concentrations of all heavy metals ( $\mathrm{As}, \mathrm{Pb}, \mathrm{Cr}, \mathrm{Cd}$, $\mathrm{Ni}$, and $\mathrm{Hg}$ ) were less than the criterion.

\subsection{Biomass and growth of rice plants}

The effect of time for sun drying of moist sludge (D) on dried weight of shoot, dried weight of root and height was not different, while the number of tillers was significantly different at $P<0.05$. Significant differences existed in the influence of sludge piling depths on the growth of the Chainat1 rice cultivars plants at $P<0.01$ as shown in Table 3.(Table 3)

Shoot and root weight were significantly higher in plants grown at a depth of sludge piling at $30 \mathrm{~cm}$ compared to $10 \mathrm{~cm}$ and $20 \mathrm{~cm}$. For the plant height, only the plants grown in the treatment sludge of a piling depth at $30 \mathrm{~cm}$ could reach the average height of the Chainat 1 cultivar $(113 \mathrm{~cm})$ as shown in Table3. The rice plants grown in the treatment sludge of a piling depth at $30 \mathrm{~cm}$ showed the highest numbers of tillers per pot $^{-1}$.

All the biomass and growth parameters of rice grown in moist sludge showed positive response under both time for sun drying of moist sludge and sludge piling depth. Sewage sludge is rich in nutrients especially nitrogen which led to better rice tiller production. At the vegetative phase, nitrogen plays an important role in tiller production (Wattanaporn, 2001). Kiuchi and Ishizaka (1964) stated that the emergence of tillers was more favorably influenced by the absorption rate of nitrogen than by nitrogen in the plant during the tillering period. So that the more nitrogen applied (more sludge piling depth), the more tillers were produced as evidenced by this result. The result was supported by the study of Voos and Sabey (1987) that mineralization of organic $\mathrm{N}, \mathrm{NH}_{4}{ }^{+}$ $-\mathrm{N}$ increased significantly as the sludge rate increased.

Mineralization of soil organic $\mathrm{N}$ in flooded soils is the key process for $\mathrm{N}$ nutrition of lowland rice (Keeney and Sahrawat, 1986). Even in well-fertilized lowland rice fields, rice utilizes 50-75 per cent of soil N through mineralization (Broadbent FE 1978, IAEA 1978, Koyama 1981 and Sahrawat 1983b). There are two major forms of $\mathrm{N}$ that can be taken up by plants; $\mathrm{NH}_{4}{ }^{+}-\mathrm{N}$ and $\mathrm{NO}_{3}{ }^{-} \mathrm{N}$. Referring to the experiment of Wattanaporn (2001), under flooding conditions, both $\mathrm{NH}_{4}^{+}-\mathrm{N}^{+}$and $\mathrm{NO}_{3}-\mathrm{N}$ forms were detected only at the first day after transplanting (DAT) and thereafter only $\mathrm{NH}_{4}{ }^{+}-\mathrm{N}$ remained in the systems. This is because $\mathrm{NO}_{3}{ }^{-} \mathrm{N}$ which has been presented in the aerobic layer of soil became defused and perhaps leached into the underlying anaerobic layer (Patrick et al., 1985) within 6 to 8 days after flooding (Wattanaporn, 2001). As shown in Figure. 1, the numbers of tillers in all treatments increased rapidly from 3 to 7 weeks after transplanting and then they tended to be constant from week 7 till harvesting, which related to Serna and Pomares (1992) that anaerobically digested sludge showed a rapid initial release of organic $\mathrm{N}$ during the initial 2 or 4 weeks, followed by a relatively constant rate of mineralization by weeks $4-8$, and then it tended to increase slowly from 8 to 16 . These results were supported by the study of Ramanathan and Krishnamoorthy (1973) that from 59 to 84 per cent of the nutrients present in the ripe plants were absorbed between tillering and flowering. More than 90 per cent of the $\mathrm{N}$ may enter the crop within 52 days after planting and uptake of $\mathrm{N}$ increases until tillering.(Figure 1)

\subsection{Yield}

The effect of time for sun drying of moist sludge (D) on thousand seed weight was significantly different ( $p<$ 0.05 ) compared to other parameters; no. of ears (plant-1), grain weight (g plant-1), yield (g m-2), harvest index with difference at $p<0.01$ and no. of grain (plant-1) with no difference respectively. For the sludge piling depths, all yield parameters were significantly different $(\mathrm{P}<0.05)$ except the thousand seed weight $(\mathrm{g})$ parameter (Table4).

Grain yield increased significantly in plants grown at all sludge piling depths particularly at $30 \mathrm{~cm}$. Singh and Agrawal (2010) reported sewage sludge amendment rates above $4.5 \mathrm{~kg} \mathrm{~m}^{-2}$ increased the yield of rice. The dewatered municipal sludge application in the range of 165-495 t/ha was found to be positive on Canna growth (Li, S. et al, 2009). The yield of The Chainat 1 (Oryza sativa L. cv. Chainat 1 ranges between $0.45 \mathrm{~kg} \mathrm{~m}^{-2}$ in rainy season to $0.47 \mathrm{~kg} \mathrm{~m}^{-2}$ in dry season (Rice Research Institute, 2005), compared to the experiment of only rice plants grown in a sludge piling depth at $30 \mathrm{~cm}(1,440 \mathrm{t} / \mathrm{ha})$ which can produce a higher grain yield $(0.63 \mathrm{~kg}$ $\mathrm{m}^{-2}$ ) than the average.

\section{Conclusion}

The present study clearly indicates that moist sewage sludge from community wastewater treatment can be used to grow rice (Oryaza sativa $\mathrm{L}$ ) under the present set of experimental conditions with sufficient nitrogen. With the non significant effects for sun drying of moist sludge on the growth and the yield of Chinat 1 rice cultivar plants, 
therefore there is no need for drying and grinding sludge before growing rice. In addition, applying sludge more than $1,440 \mathrm{t} / \mathrm{ha}$ or a piling depth of $30 \mathrm{~cm}$ can produce higher grain yield. Field experiments are needed for further investigation. Care should be taken to assess the level of metals in the edible portion of the plants.

\section{References}

Allen, S.E., Grimshaw, H.M., Rowland, A.P. (1986). Chemical analysis. In: Moore, P.D., Chapman, S.B. (Eds.), Methods in Plant Ecology. Blackwell Scientific Publication, Oxford, London.

Banerjee, M.R., Burton, D.L., Depoe, S. (1997). Impact of sewage sludge application on soil biological characteristics. Agric. Ecosyst. Environ, 66, 241-249.

Bertoncini, E.I., D'Orazio, V., Senesi, N., Mattiazzo, M.E. (2008). Effects of sewage sludge amendment on the properties of two Brazilian oxisols and their humic acids. Bioresour. Technol, 99 (11), 4972-4979.

BMA (Bangkok Metropolitan Administration). (1997). Department of Drainage and Sewage report, Drainage and Sewerage Department, Bangkok, Thailand.

BMA (Bangkok Metropolitan Administration). (2008). Department of Drainage and Sewage report, Drainage and Sewerage Department, Bangkok, Thailand.

Bray, R.H. and Kurtz, L. T. (1945). Determination of Total, Organic, and Available Forms of Phosphorus in Souls. Soil Science, 59:39-45.

Bremner, J.M. (1960). Determination of nitrogen in soild by the Kjeldahl method. J. Agric. Sci., 55, 11-33.

Broadbent FE. (1978). Transformations of soil nitrogen. In Nitrogen and rice, pp. 543-559. Los Banos, Philippines: IRRI.

De Datta, S.K. (1981). Principles and Practices of Rice Production. Wiley \& Sons, Singapore.

Dolgen, D., Necdet Alpaslan, M., Delen, N. (2007). Agricultural recycling of treatment plant sludge: a case study for a vegetable-processing factory. Journal of Environmental Management, 84, 274-281.

Epstein, E. (1975). Effect of sewage sludge on some soil physical properties. J.Environ. Qual, 4, 139-142.

IAEA. (1978). Isotope studies on rice fertilization. Joint FAO/IAEA Div of Atomic Energy in Food Agric Tech Rep Ser No 181, IAEA, Vienna.

Keeney DR and Sahrawat KL. (1986). Nitrogen transformations in flooded rice soils. Fert Res, 9:15-38, Natherlands.

Kiuchi, T., and Ishizaka, H. (1960). Effect of Nutrient on Yield Constituting Factors of Rice (Nitrogen). Journal Science Soil and Manure, Japan. 31:285-291.

Koyama T. (1981). The transformations and balance of nitrogen in Japanese paddy fields. Fert Res, 2:261-278.

Li, S., Zhang, K., Zhou, S., Zhang, L., Chen, Q. (2009). Use of dewatered municipal sludge on Canna growth in pot experiments with a barren clay soil. Waste Management. doi:10.1016/j.wasman.2008.12.007, http://dx.doi.org/10.1016/j.wasman.2008.12.007

Martinez, F., Cuevas, G., Calvo, R., Walter, I. (2003). Biowaste effects on soil and native plants in a semiarid ecosystem. J. Environ. Qual., 32, 472-479.

McLean, E. O. and Watson, M. E. (1985). Soil Measurement of Plant-Available Potassium. In Potassium in Agriculture, ed. R.D. Munson. Pp. 277-308. American Society of Agronomy. Madison, W.L.

Olsen S. R. and Sommers, L.E. (1982). Phosphorus. In Method of Soil Analysis PartII: Chemical and Microbiological Properties, eds. A.L. Page, R.H. Miller and M.R. Keeney, $2^{\text {nd }}$ Edition. ASA and SSSA, Inc. Publisher, Madison, WI, US.

Patrick, W. H., Mikkelsen, D.S. and Wells, B. R. (1985). Plant Nutrient Behavior in Flooded Soil. In Fertilizer technology and use, eds. F.C. Boswell, T.C. Tucker, L.F. Welch, O.P. Engelstad. Soil Science, Society of America, Inc. Wisconsin, USA.

Quevauviller, P., Rauret, R., Rubio, G., Lopezsanchez, J.F., Ure, A.M., Bacon, J.R., Muntau, H. (1997). Certified reference materials for the quality control of EDTA and acetic acid-extractable contents of trace elements in sewage sludge amended soils (CRMs 483 and 484). Fresenius'J.Anal.Chem. 357, 611-618.

Rice Research Institute. (2005). DOA Plant KnowledgeBase. [Online] Available from: http:// www.doa. go.th/data-agri/RICE/3 var/var 01.html.

Sahrawat KL. (1983b). Nitrogen availability indexes for submerged rice soils. Adv Agron 36:415-451. 
Schnitzer, M. (1982). Soil Organic Matter. In: Method of Soil Analysis Part II: Chemical and Microbiological Properties, eds. A. L. Page, R.H. Miller and M.R. Keeney, $2^{\text {nd }}$ Edition. ASA and SSA, Inc. Publisher, Madison. OE, US.

Serna, M. D. and Pomares, F. (1992). Nitrogen Mineralization of Sludge-Amended Soil. Bioresource Technology, 39:285-290.

Singh, R.P., Agrawal, M. (2010). Variations in heavy metal accumulation, growth and yield of rice plants grown at different sewage sludge amendment rates. Eotoxicol. Environ. Saf, doi:10.1016/j.ecoenv.2010.01.020, http://dx.doi.org/10.1016/j.ecoenv.2010.01.020

Siriratpiriya, O., Chuaygud, and Chobkatanyoo, S. (2009). Replacement of fertilizers with sludge and rubber latex lutiod for nursing poly-bag rubber. Kasetsart University Annual Conference, Bangkok (Thailand), 17-20 Mar 2009.

Stoll, U. (1995). Municipal sewage sludge management, Environ. Systems Reviews. Environ. Systems Information Center (ENSIC). 39, Bangkok, Thailand.

Thepphituk, S. (2000). Sediment accumulation in the wastewater collecting system and lagoon treatment system, Changwat Phetchaburi. Thesis. Kasetsart University.

U.S. Environmental Protection Agency. (1999). Biosolids generation, use and disposal in the United States. Municipal and Industrial Solid Waste Division, Office of Solid Waste; EPA-530-R-99-009, 74 pp.

Voos, G., Sabey, B. R. (1987). Nitrogen mineralization in Sewage Sludge-Amended Coal Mine Soil and Topsoils. Journal of environmental quality, 16:231-237.

Walkley, A. and Black., I. A. (1934). An Examination of the Degtjareff Method for Determining Soil Organic Matter and a Proposal Modificaiton of the Chromic Acid Titration Method. Soil Science, 37:29-38.

Wattnanaporn M. (2001). Benefits and risks of using a combination of sewage sludge and chemical fertilizer on rice in acid sulfate soil. Thesis. Kasetsart University.

Table 1. Sludge treatments used in the experiments

\begin{tabular}{|l|l|l|l|l|}
\hline Sludge treatments & Days of sun drying & Depth $(\mathrm{cm})$ of sludge piling & Sludge $(\mathrm{kg})$ & Application rate $(\mathrm{t} / \mathrm{ha})$ \\
\hline D0H10 & 0 & 10 & 6.25 & 480 \\
\hline D0H20 & 20 & 12.50 & 960 \\
\hline D0H30 & & 30 & 18.75 & 1,440 \\
\hline D3H10 & 10 & 6.25 & 480 \\
\hline D3H20 & 20 & 12.50 & 960 \\
\hline D3H30 & & 30 & 18.75 & 1,440 \\
\hline D6H10 & 6 & 10 & 6.25 & 480 \\
\hline D6H20 & & 20 & 12.50 & 960 \\
\hline D6H30 & & 30 & 18.75 & 1,440 \\
\hline D9H10 & 10 & 6.25 & 480 \\
\hline D9H20 & & 20 & 12.50 & 960 \\
\hline D9H30 & & 30 & 18.75 & 1,440 \\
\hline D12H10 & 12 & 10 & 6.25 & 480 \\
\hline D12H20 & 20 & 12.50 & 960 \\
\hline D12H30 & & 30 & 18.75 & 1,440 \\
\hline D15H10 & 15 & 10 & 6.25 & 480 \\
\hline D15H20 & & 20 & 12.50 & 960 \\
\hline D15H30 & & 30 & 18.75 & 1,440 \\
\hline D18H10 & 18 & 10 & 6.25 & 480 \\
\hline D18H20 & & 20 & 12.50 & 960 \\
\hline D18H30 & & 30 & 18.75 & 1,440 \\
\hline
\end{tabular}


Table 2. Physical and Chemical properties of sludge used in this experiment

\begin{tabular}{|c|c|c|}
\hline Parameters & Sludge & Thailand quality standards* \\
\hline $\mathrm{pH}(1: 1)$ & 6.8 & \\
\hline $\mathrm{EC}\left(\mathrm{dS} \mathrm{cm}^{-1}\right)$ & 12.51 & \\
\hline Organic matter $(\%)$ & 15.90 & \\
\hline $\operatorname{CEC}\left(\mathrm{cmol}\left(\mathrm{p}^{+}\right) \mathrm{kg}^{-1}\right)$ & 34 & \\
\hline Total nitrogen $(\%)$ & 1.05 & \\
\hline Total phosphorus (mg/kg) & 258 & \\
\hline Potassium $(\mathrm{mg} / \mathrm{kg})$ & 620 & \\
\hline Calcium $(\mathrm{mg} / \mathrm{kg})$ & 5200 & \\
\hline Magnesium (mg/kg) & 1198 & \\
\hline Moisture (\%) & 87.4 & \\
\hline $\mathrm{Pb}\left(\mathrm{mg} \mathrm{kg}^{-1}\right)$ & 48.1 & $\mathrm{mg} / \mathrm{kg}$ \\
\hline $\mathrm{Cr}\left(\mathrm{mg} \mathrm{kg}^{-1}\right)$ & 37.6 & $<300 \quad \mathrm{mg} / \mathrm{kg}$ \\
\hline $\mathrm{Cd}\left(\mathrm{mg} \mathrm{kg}^{-1}\right)$ & 1.7 & $\mathrm{mg} / \mathrm{kg}$ \\
\hline $\mathrm{Ni}\left(\mathrm{mg} \mathrm{kg}^{-1}\right)$ & 18.4 & $<1,600 \mathrm{mg} / \mathrm{kg}$ \\
\hline $\mathrm{Hg}\left(\mathrm{mg} \mathrm{kg}^{-1}\right)$ & 2.3 & $<23 \quad \mathrm{mg} / \mathrm{kg}$ \\
\hline $\mathrm{As}\left(\mathrm{mg} \mathrm{kg}^{-1}\right)$ & 0.09 & $\mathrm{mg} / \mathrm{kg}$ \\
\hline
\end{tabular}

All values based on dry weight

*Thailand soil criteria for agricultural use (PCD: Soil Quality Standards)

Table 3. The effects of various sludge piling depths and time for sun drying of moist sludge on the growth of the Chinat 1 rice cultivar plants at harvesting: dried weight of shoot, dried weight of root, height and numbers of tillers per pot

a. F value, MS error and CV

\begin{tabular}{|l|l|l|l|l|l|}
\hline \multicolumn{1}{|c|}{ SOV } & Df & Shoot weight & Root weight & Height & Number of tillers pot \\
\hline $\begin{array}{l}\text { Time for sun drying } \\
\text { of moist sludge (D) }\end{array}$ & 6 & $1.42^{\mathrm{NS}}$ & $1.12^{\mathrm{NS}}$ & $1.08^{\mathrm{NS}}$ & $3.02^{*}$ \\
\hline Sludge piling depths (H) & 2 & $220.65^{* *}$ & $64.67^{* *}$ & $25.59^{* *}$ & $160.80^{* *}$ \\
\hline D x H & 12 & $1.66^{\mathrm{NS}}$ & $1.64^{\mathrm{NS}}$ & $1.63^{\mathrm{NS}}$ & $0.76^{\mathrm{NS}}$ \\
\hline MS Error & & 37.27 & 85.77 & 42.56 & 21.32 \\
\hline CV (\%) & & 14.09 & 25.11 & 6.13 & 16.10 \\
\hline
\end{tabular}

Correlation coefficients obtained as a result of application of the nonlinear least squares equation:*, **, significant at the 0.05 and 0.001 levels, respectively.

b. The effect of time for sun drying of moist sludge on the growth of the Chinat 1 rice cultivar plants

\begin{tabular}{|c|c|c|c|c|}
\hline Time for sun drying of moist sludge & Shoot weight $\left(\right.$ g plant $\left.^{-1}\right)$ & $\begin{array}{c}\text { Root weight } \\
\left(\mathrm{g}_{\text {plant }}{ }^{-1}\right)\end{array}$ & $\begin{array}{l}\text { Height } \\
(\mathrm{cm})\end{array}$ & Number of tillers pot ${ }^{-1}$ \\
\hline $\mathrm{D}_{0}$ & $43.85^{\mathrm{ab}}$ & $38.10^{\mathrm{a}}$ & $108.89^{\mathrm{a}}$ & $25.11^{\mathrm{c}}$ \\
\hline $\mathrm{D}_{3}$ & $45.46^{\mathrm{a}}$ & $39.98^{\mathrm{a}}$ & $104.89^{\mathrm{a}}$ & $28.44^{\mathrm{abc}}$ \\
\hline $\mathrm{D}_{6}$ & $46.07^{\mathrm{a}}$ & $38.13^{\mathrm{a}}$ & $108.33^{\mathrm{a}}$ & $27.22^{\mathrm{bc}}$ \\
\hline$\frac{D_{6}}{D_{9}}$ & $43.60^{\mathrm{ab}}$ & $32.72^{\mathrm{a}}$ & $108.33^{\mathrm{a}}$ & $28.78^{\mathrm{abc}}$ \\
\hline $\mathrm{D}_{12}$ & $38.59^{\mathrm{b}}$ & $38.01^{\mathrm{a}}$ & $104.56^{\mathrm{a}}$ & $32.67^{\mathrm{a}}$ \\
\hline $\mathrm{D}_{15}$ & $43.15^{\mathrm{ab}}$ & $39.44^{\mathrm{a}}$ & $103.11^{\mathrm{a}}$ & $31.67^{\mathrm{ab}}$ \\
\hline $\mathrm{D}_{18}$ & $42.66^{\mathrm{ab}}$ & $31.77^{\mathrm{a}}$ & $107.11^{\mathrm{a}}$ & $26.89^{\mathrm{bc}}$ \\
\hline
\end{tabular}

Different letters in each group show significance at $p<0.05$.

c. The effect of sludge piling depths on the growth of the Chinat 1 rice cultivar plants

\begin{tabular}{|l|l|l|l|l|}
\hline Sludge piling depths & $\begin{array}{c}\text { Shoot weight } \\
\left.\text { g plant }^{-1}\right)\end{array}$ & $\begin{array}{c}\text { Root weight } \\
\left.\text { g plant }^{-1}\right)\end{array}$ & $\begin{array}{c}\text { Height } \\
(\mathrm{cm})\end{array}$ & Number of tillers pot \\
\hline $10 \mathrm{~cm}\left(\mathrm{H}_{10}\right)$ & $21.56^{\mathrm{c}}$ & $19.42^{\mathrm{c}}$ & $99.05^{\mathrm{c}}$ & $15.57^{\mathrm{c}}$ \\
\hline $20 \mathrm{~cm}\left(\mathrm{H}_{20}\right)$ & $48.25^{\mathrm{b}}$ & $39.66^{\mathrm{b}}$ & $106.91^{\mathrm{b}}$ & $29.38^{\mathrm{b}}$ \\
\hline $30 \mathrm{~cm}\left(\mathrm{H}_{30}\right)$ & $60.21^{\mathrm{a}}$ & $51.56^{\mathrm{a}}$ & $113.43^{\mathrm{a}}$ & $41.10^{\mathrm{a}}$ \\
\hline
\end{tabular}

Different letters in each group show significance at $p<0.05$. 
Table 4. The effect of various sludge piling depths and time for sun drying of moist sludge on the yield of the Chinat1 rice cultivar plants at harvesting : no. of ears (plant-1), no. of grain (plant-1), grain weight (g plant-1), thousand seed weight $(\mathrm{g})$, yield (g m-2) and harvest index

a. F value, MS error and CV

\begin{tabular}{|l|l|l|l|l|l|l|l|}
\hline \multicolumn{1}{|c|}{ SOV } & df & $\begin{array}{c}\text { No. of ears } \\
\left.\text { plant }^{-1}\right)\end{array}$ & $\begin{array}{c}\text { No. of grain } \\
\left(\text { plant }^{-1}\right)\end{array}$ & $\begin{array}{c}\text { Grain weight } \\
\left(\mathrm{g} \mathrm{plant}^{-1}\right)\end{array}$ & $\begin{array}{c}\text { Thousand seed } \\
\text { weight }(\mathrm{g})\end{array}$ & $\begin{array}{c}\text { Yield (g } \\
\left.\mathrm{m}^{-2}\right)\end{array}$ & $\begin{array}{c}\text { Harvest } \\
\text { Index }\end{array}$ \\
\hline $\begin{array}{l}\text { Time for sun } \\
\text { drying of moist } \\
\text { sludge (D) }\end{array}$ & 6 & $2.48^{*}$ & $1.44^{\mathrm{NS}}$ & $3.57^{*}$ & $4.28^{* *}$ & $3.57^{*}$ & $2.71^{*}$ \\
\hline $\begin{array}{l}\text { Sludge piling } \\
\text { depths (H) }\end{array}$ & 2 & $235.66^{* *}$ & $20.60^{* *}$ & $263.42^{* *}$ & $1.95^{\mathrm{NS}}$ & $263.42^{* *}$ & $12.83^{* *}$ \\
\hline D x H & 12 & $1.92^{\mathrm{NS}}$ & $0.97^{\mathrm{NS}}$ & $2.42^{*}$ & $2.31^{*}$ & $2.42^{*}$ & $1.29^{\mathrm{NS}}$ \\
\hline MS Error & & 11.46 & 109.94 & 65.35 & 2.61 & 4116.32 & 0.03 \\
\hline CV (\%) & & 13.45 & 11.60 & 15.41 & 6.14 & 15.41 & 15.31 \\
\hline
\end{tabular}

Correlation coefficients obtained as a result of application of the nonlinear least squares equation:*,**, significant at the 0.05 and 0.001 levels, respectively.

b. The effect of time for sun drying of moist sludge on the growth of the Chinat1 rice cultivar plants

\begin{tabular}{|l|l|l|l|l|l|l|}
\hline $\begin{array}{c}\text { Time for sun } \\
\text { drying of moist } \\
\text { sludge }\end{array}$ & $\begin{array}{c}\text { No. of ears } \\
\text { (plant-1) }\end{array}$ & $\begin{array}{c}\text { No. of grain } \\
\text { (plant }{ }^{-1}\end{array}$ & $\begin{array}{c}\text { Grain weight } \\
\left(\mathrm{g}_{\text {plant }}{ }^{-1}\right)\end{array}$ & $\begin{array}{c}\text { Thousand seed } \\
\text { weight }(\mathrm{g})\end{array}$ & $\begin{array}{c}\text { Yield (g } \\
\left.\mathrm{m}^{-2}\right)\end{array}$ & $\begin{array}{c}\text { Harvest } \\
\text { Index }\end{array}$ \\
\hline $\mathrm{D}_{0}$ & $25.56^{\mathrm{ab}}$ & $88.83^{\mathrm{ab}}$ & $56.23^{\mathrm{ab}}$ & $26.57^{\mathrm{a}}$ & $446.27^{\mathrm{ab}}$ & $1.24^{\mathrm{ab}}$ \\
\hline $\mathrm{D}_{3}$ & $26.22^{\mathrm{a}}$ & $89.28^{\mathrm{ab}}$ & $54.11^{\mathrm{ab}}$ & $27.05^{\mathrm{a}}$ & $429.45^{\mathrm{ab}}$ & $1.10^{\mathrm{b}}$ \\
\hline $\mathrm{D}_{6}$ & $26.00^{\mathrm{a}}$ & $88.09^{\mathrm{ab}}$ & $55.78^{\mathrm{ab}}$ & $27.29^{\mathrm{a}}$ & $442.71^{\mathrm{ab}}$ & $1.17^{\mathrm{ab}}$ \\
\hline $\mathrm{D}_{9}$ & $27.67^{\mathrm{a}}$ & $92.81^{\mathrm{ab}}$ & $58.93^{\mathrm{a}}$ & $26.92^{\mathrm{a}}$ & $467.70^{\mathrm{a}}$ & $1.33^{\mathrm{a}}$ \\
\hline $\mathrm{D}_{12}$ & $24.33^{\mathrm{ab}}$ & $85.79^{\mathrm{b}}$ & $49.00^{\mathrm{bc}}$ & $26.42^{\mathrm{a}}$ & $388.92^{\mathrm{bc}}$ & $1.24^{\mathrm{ab}}$ \\
\hline $\mathrm{D}_{15}$ & $24.33^{\mathrm{ab}}$ & $89.43^{\mathrm{ab}}$ & $47.98^{\mathrm{bc}}$ & $24.00^{\mathrm{b}}$ & $380.79^{\mathrm{bc}}$ & $1.07^{\mathrm{b}}$ \\
\hline $\mathrm{D}_{18}$ & $22.11^{\mathrm{b}}$ & $98.66^{\mathrm{a}}$ & $45.15^{\mathrm{c}}$ & $25.93^{\mathrm{a}}$ & $358.32^{\mathrm{c}}$ & $1.08^{\mathrm{b}}$ \\
\hline $\mathrm{D}^{\mathrm{b}}$ & & & & & \\
\hline
\end{tabular}

Different letters in each group show significance at $p<0.05$.

c. The effect of sludge piling depths on the growth of the Chinat1 rice cultivar plants

\begin{tabular}{|l|l|l|l|l|l|l|}
\hline $\begin{array}{c}\text { Sludge piling } \\
\text { depths }\end{array}$ & $\begin{array}{c}\text { No. of ears } \\
\text { (plant-1) }\end{array}$ & $\begin{array}{c}\text { No. of grain } \\
\left(\text { plant }^{-1}\right)\end{array}$ & $\begin{array}{c}\text { Grain weight } \\
\left(\mathrm{g} \mathrm{plant}^{-1}\right)\end{array}$ & $\begin{array}{c}\text { Thousand seed } \\
\text { weight }(\mathrm{g})\end{array}$ & $\begin{array}{c}\text { Yield }(\mathrm{g} \\
\left.\mathrm{m}^{-2}\right)\end{array}$ & $\begin{array}{c}\text { Harvest } \\
\text { Index }\end{array}$ \\
\hline $10 \mathrm{~cm}\left(\mathrm{H}_{10}\right)$ & $13.14^{\mathrm{c}}$ & $78.92^{\mathrm{b}}$ & $22.70^{\mathrm{c}}$ & $25.75^{\mathrm{a}}$ & $180.18^{\mathrm{c}}$ & $1.06^{\mathrm{b}}$ \\
\hline $20 \mathrm{~cm}\left(\mathrm{H}_{20}\right)$ & $26.71^{\mathrm{b}}$ & $93.19^{\mathrm{a}}$ & $54.85^{\mathrm{b}}$ & $26.63^{\mathrm{a}}$ & $435.28^{\mathrm{b}}$ & $1.14^{\mathrm{b}}$ \\
\hline $30 \mathrm{~cm}\left(\mathrm{H}_{30}\right)$ & $35.67^{\mathrm{a}}$ & $99.13^{\mathrm{a}}$ & $79.82^{\mathrm{a}}$ & $26.56^{\mathrm{a}}$ & $633.46^{\mathrm{a}}$ & $1.33^{\mathrm{a}}$ \\
\hline
\end{tabular}

Different letters in each group show significance at $p<0.05$.

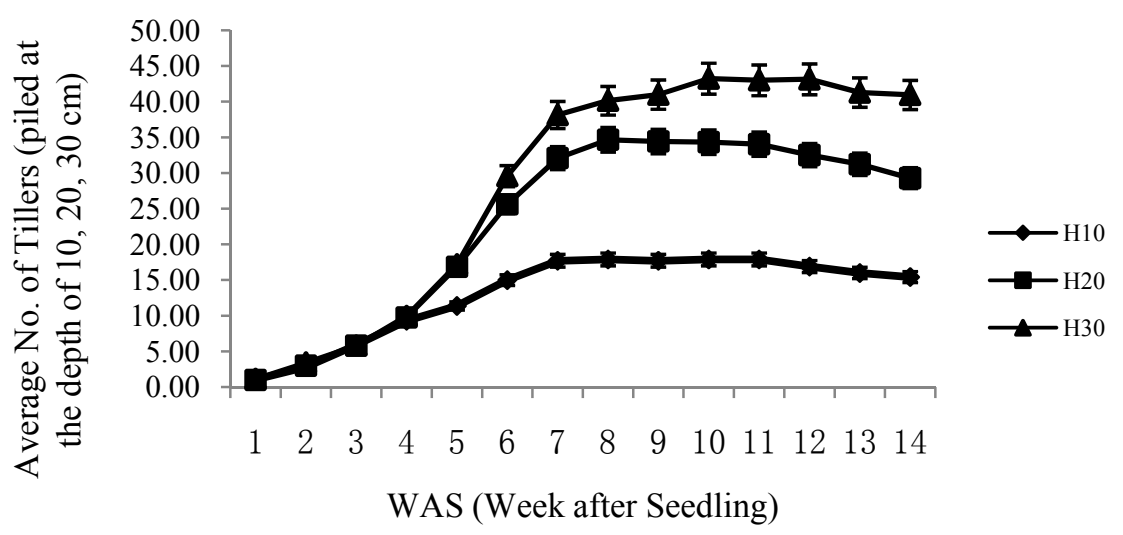

Figure 1. The increase of tillers during the weeks after seedling until harvesting at the sludge piling depth of 10 , 20 and $30 \mathrm{~cm}$ 